FACTA UNIVERSITATIS

Series: Linguistics and Literature Vol. 18, $\mathrm{N}^{\mathrm{o}} 2$, 2020, pp. 131-150

https://doi.org/10.22190/FULL2002131B

Original Scientific Paper

\title{
CRITICAL INCIDENTS AS A MEANS OF DEVELOPING AND ASSESSING EFL MAJORS' INTERCULTURAL SENSITIVITY AND COMPETENCE
}

\author{
UDC 81'243:316.72 \\ 371.3:81'243
}

\section{Radmila Bodrič}

University of Novi Sad, Faculty of Philosophy, Novi Sad, Serbia

\begin{abstract}
Knowing and understanding the cultural values of one's native and target cultures enable individuals to establish and maintain successful intercultural communication. The aim of the paper is to identify the EFL university students' opinions and attitudes towards potentially controversial intercultural situations. For this purpose, a qualitative critical incident technique was used to explore whether (and to what extent) pre-service EFL student teachers possess intercultural sensitivity and competence to resolve controversial intercultural situations presented through so-called critical incidents. The survey was carried out among third and fourth-year students of English at the Faculty of Philosophy, University of Novi Sad. The research findings indicate that the respondents demonstrated a fair degree of intercultural perspective, intercultural sensitivity and competence. The findings offer practical support in favour of critical incidents as one of the many useful pedagogical tools for the development and assessment of intercultural sensitivity and competence of L2 learners. The pedagogical implications of this research point towards the necessity of introducing intercultural elements not only into L2 instruction but into general education as well.
\end{abstract}

Key words: EFL majors, intercultural sensitivity, intercultural competence, critical incidents, intercultural communication

\section{INTRODUCTION}

Intercultural competence has always been part of human culture from early civilizations that thrived on trade to today's world of information and communication technologies where we can get in touch with anyone in a matter of seconds. No country or society in

Submitted August 23, 2020; Accepted September 16, 2020

Corresponding author: Radmila Bodrič

University of Novi Sad, Faculty of Philosophy

E-mail: radmila.bodric@gmail.com 
the world today is homogeneous regarding nationality, class, race, language, etc. It is diversity that lies at the core of human existence. Cultural differences imply different cultural and social norms, values, beliefs, attitudes. Therefore, it can be claimed that no culture is inherently greater than or superior to other cultures (Huitt 2020). Meeting, communicating and living with diverse cultural groups within and across countries only add to the mutual gains in all spheres of life.

Ever-increasing cultural diversity all over the globe calls for significant intercultural skills which enable us to live and work with people from different cultures. People may have either positive or negative attitudes towards cultural differences. Those who have negative attitudes towards otherness, i.e. people and cultures different from their own may develop stereotypes, prejudices, intolerance or even hostility. By contrast, people cultivating positive or constructive attitudes towards people different from themselves develop curiosity and openness, and show appreciation, tolerance and respect for them. It is understood that positive attitudes towards cultural differences unquestionably underlie successful intercultural encounters, and "all communication is to some degree intercultural" (Scollon, Scollon, and Jones 2012, 2, as cited in Paunović 2013, 48).

According to Chen and Starosta (1998, as cited in Samovar et al. 2013, 468) intercultural awareness is a cognitive perspective of intercultural communication. It embodies knowing and understanding the distinct cultural values (differences and similarities) of one's own and other cultures, thereby helping individuals to overcome misunderstandings in intercultural encounters. However, in order for intercultural communication to be successful, intercultural awareness needs to be complemented by its affective counterpart - intercultural sensitivity. Intercultural sensitivity manifests itself in the feelings of emotional empathy, willingness to understand, respect, tolerate and accept cultural differences (Chen and Young 2012, as cited in Samovar et al. 2013, 468). According to Samovar et al. $(2013,469)$ intercultural sensitivity is "accepting differences through tolerance" and is considered crucial for the promotion of intercultural dialogue. Intercultural communicative competence represents an intersection of a whole range of culturally appropriate behaviour, knowledge, skills, attitudes and values that enable individuals to interact effectively and appropriately with people from different cultures (Bandura 2011; Bennett 2011; Byram 1997, 2000; Cushner 2015; Kiliańska-Przybyło 2017; Lazarević 2017; Paunović 2013; Petrović 2018). The acquisition of intercultural competence takes a lot of time, effort and care, and should be an indispensable part and/or outcome of overall education.

This paper aims at identifying the opinions and attitudes of EFL university students towards cultural misunderstandings and breakdowns. The EFL majors' possession of emotional empathy and readiness to solve potentially controversial intercultural situations in a constructive fashion will demonstrate their intercultural perspective (or lack thereof), and the level of their intercultural sensitivity and competence. The respondents were third and fourth-year EFL majors from the Department of English Studies, Faculty of Philosophy, University of Novi Sad. The respondents' views on conflicting intercultural episodes (adapted from Lazarević 2013; 2017) were elicited by using a critical incident technique (CIT) - a widely used qualitative research method in the intercultural field. CIT was purposely used as it is adequate for both intercultural instruction and assessment, it is learner-friendly and is recognised by many researchers as an effective exploratory and investigative tool (Butterfiled et al. 2005; Breunig \& Christoffersen 2016; Cushner 2014; Cushner and Brislin 1996; Méndez García 2016; Spencer-Oatey \& Harsch 2013). 


\section{THEORETICAL BACKGROUND}

\subsection{Intercultural learning: significance and implications for stakeholders in education}

In today's post-method era, foreign/second language (L2) instruction has been increasingly sensitive to the complex and dynamic issue of culture. The prevalent intercultural approach to language learning and intercultural competence as its desired outcome assume that culture is more of a process in which learners actively engage, rather than a closed set of cultural information that learners are required to passively acquire and recall (Ho 2009, 65; Liddicoat, Scarino 2013, 23). In the last three decades, intercultural L2 learning has become a crucial focus of modern L2 education. It reflects a greater awareness of the interrelatedness and inseparability of language and culture, and the urge to prepare L2 learners for intercultural communication in our increasingly diverse society. Intercultural competence, featuring as a goal of foreign language pedagogy, is widely being promoted as a way to develop the ability of individuals to interact appropriately and effectively with those from other cultural backgrounds (Ho 2009; Moeller and Nugent 2014; Sinicrope, Norris, and Watanabe 2007). Understanding culture hence becomes a constituent element of intercultural competence.

Developing intercultural competence facilitates mediation between languages and cultures and the identities that they frame. Furstenberg $(2010,329)$ rightfully claims that "culture is a highly complex, elusive, multilayered notion that encompasses many different and overlapping areas and that inherently defies easy categorization and classification". Just as culture is difficult to define, so is intercultural competence as it inevitably includes cultural elements. There are so many definitions and interpretations of intercultural competence, which depend on the areas explored by researchers (Lazarević 2013). Liddicoat and Scarino $(2013,23)$ explain that intercultural competence means: that one's practices are influenced by the cultures to which one belongs (both the speaker and the interlocutor), that there is no one 'correct' or 'fixed' way of doing things, that one should value one's own and other cultures, then use language to explore culture and use one's background cultural knowledge to deepen their understanding of new cultures, then find one's meaningful ways of participating in intercultural interaction and an idiosyncratic intercultural style and identity. According to Liddicoat and Scarino $(2013,24)$, interculturally competent learners are aware that cultures are relative, that all behaviours are culturally variable and that it is necessary for them to "build connections within and across interactions and experiences" and to develop a sensitivity to the culturally diverse world around them (Liddicoat and Scarino 2013, 81).

The best-known model of intercultural competence, upon which most definitions are based, is the one provided by Byram (1997). Byram's conceptualisation of intercultural communicative competence entitled Multidimensional Model of Intercultural Competence strongly influenced the definition of intercultural competence in the CEFR $(2001,2018)$, as well as in many national education standards and L2 curricula worldwide. Byram made it clear that the purpose of the model was to help L2 educators understand the concept of intercultural competence. Intercultural competence comprises three domains: the affective domain (attitudes), the cognitive domain (knowledge) and the behavioural domain (skills), all of which are necessary for one to interact successfully in intercultural situations. Attitudes are described in terms of curiosity, openness, empathy, cultural sensitivity, respect for otherness, and positive views towards other cultures (Byram 1996, as cited in Spencer-Oatey and Franklin 2009, 66; Lazarević 2013, 53). Attitudes also relate to the ability of individuals to 
decentre from their own cultural perspective by questioning assumptions and prior knowledge about other cultures and their own as well. Knowledge, the cognitive dimension of intercultural competence, concerns "knowledge about social groups and their cultures in one's own country, and similar knowledge of the interlocutor's country" as well as "knowledge of the processes of interaction at individual and societal levels" (Byram 1997, 35). These types of knowledge include linguistic and cultural behaviour of the participants in intercultural communication, which help them cope effectively with potential cultural challenges. Finally, intercultural skills (the behavioural domain), refer to: (a) the set of skills involving interpreting and relating documents or events from another culture, explaining and linking them to those from one's own culture, (b) the set of skills involving discovering and interacting, which underlie the learners' metacognition and their ability to acquire new culture-general and culture-specific knowledge and use it in real-time communication and interaction (SpencerOatey and Franklin 2009, 66), (c) critical cultural awareness, which deals with the ability to critically evaluate practices and products in one's own and other cultures and countries (Spencer-Oatey and Franklin 2009; Radić-Bojanić 2013, 2019). The aforementioned skills inevitably call for an active and responsible engagement of the participants in intercultural communication. Within the context of L2 instruction, all three dimensions of intercultural competence (attitudes, knowledge, skills) can be largely developed through education, experience and skillful instructional scaffolding.

Intercultural sensitivity is defined by some researchers as an attitude reflecting the degree of empathy, positivity and willingness to interact with people from different cultures, and is considered as a prerequisite for developing intercultural competence (Bennett 1993; Bennett and Bennett 2004; Bhawuk 1992; Bhawuk and Brislin 1992; Micó-Cebrián and Cava 2014; Chen 2010; Chen and Starosta 2004; Chen and Young 2012; Hammer, Bennett and Wiseman 2003; Hammer 2011; Ruiz-Bernardo, Ferrández-Berrueco and Sales-Ciges 2012). If learners have the will to establish intercultural communication with others, they are aware that they should first develop intercultural sensitivity and understanding and then successfully participate in a communicative act, by accepting and respecting culture within and across different languages (Radić-Bojanić 2019). The theoretical framework used by many researchers and practitioners to understand and work with intercultural sensitivity is the Developmental Model of Intercultural Sensitivity (DMIS) developed by Milton Bennett (1993). Bennett views intercultural sensitivity as an ability to understand subtle differences between cultures. This is an indicator of increased cognitive sophistication and a deeper ability to discriminate and experience relevant cultural differences, which enable one to "think and act in interculturally appropriate ways" (Hammer, Bennett and Wiseman 2003, 422; Mahon 2006, 392). For Bennett (1998), intercultural learning involves the integration of the assumptions, values and beliefs of another culture into one's own worldview (as cited in Lazarević 2013). An individual who is interculturally competent is likely to pass through six developmental stages in the process of their transformation from the 'ethnocentric' to the 'ethnorelative' stages (Radić-Bojanić 2019, 57). The ethnocentric perspective implies that one's own culture is perceived as 'central to reality', and that the ways or experiences of one's culture are seen as 'the right ways'. The ethnorelative perspective is developed to remind us that our own beliefs and behaviours are but "one organization of reality among many viable options" (Bennett 2004, 63-74, as cited in Apedaile and Schill 2008, 10; Paunović 2013, 45; Radić-Bojanić 2019, 57). There are three ethnocentric stages and three ethnorelative stages. The ethnocentric stages range from: (1) disinterest and inability to notice cultural differences, with persons isolating or separating themselves into homogeneous groups (Denial of 
cultural difference), (2) recognition of cultural differences accompanied with the feelings of threat, defensiveness and negative evaluation, and an "us-them" polarisation (Defense against cultural difference), and (3) recognition of commonality between people, meaning that all human beings are all the same... "just like me" (Minimization of cultural difference).

There are also three ethnorelative stages within which a paradigmatic shift occurs. In these stages individuals recognise that people live in culturally diverse contexts, that cultures must be understood in the context that they have developed so the individuals must search for ways to adapt to those differences. These ethnorelative stages of the continuum include: (1) the stage wherein learners recognise the possibility of different cultural norms, with one's culture seen as one of many (Acceptance of cultural difference), (2) the stage where learners shift a frame of reference, show empathy and behave according to other cultural norms and values (Adaptation to cultural difference), and (c) the stage in which individuals are capable of identifying and moving with ease in multiple cultures (Integration of cultural difference into identity). At this stage, learners successfully reconcile cultural differences and finally create a bicultural or multicultural identity. Progress from ethnocentrism to ethnorelativism is not linear, meaning that a learner might advance and slightly regress along this developmental continuum, and that not all learners will grow interculturally at the same rate (Lazarević 2013, 79; Moeller and Nugent 2014, 5). Deardorff (2006) calls the open process of developing intercultural sensitivity and competence a never-ending journey during which the learner continuously learns, changes, evolves and hopefully becomes transformed.

Cushner $(2015,11)$ explains that it is important for L2 educators to assess where the learners lie on the continuum so that they could purposely organise more structured instruction and/or interventions, which would help the learners progress more smoothly and successfully towards more advanced stages. As researchers have noted, one of the most challenging and difficult components of preparing learners for intercultural competence is assessing and measuring this process of learning (Byram 1997; Deardorff 2006; Lazarević 2018; Moloney and Harbon 2010). Byram rightfully claims that "intercultural competence cannot be assessed, or encouraged, by psychometric objective testing" (Byram 1997, 90, as cited in Lazarević 2018, 474), but rather with formative tools or process-oriented assessments, whereby students demonstrate their preferences, critically reflect on conflicting situations, consider judgments, justify their linguistic and cultural choices, etc. (Scarino 2010). In this way, the correlation between the three domains, cognitive, affective and behavioural, is viable and visible. Although objective assessment is almost impossible (Atkinson 1999; Lazarević 2009; Sercu 2004) some performance-based assessment is still necessary in order to record student intercultural learning and growth. Through different forms of assessment, learners receive feedback on their progress in intercultural understanding. All the techniques which are used for intercultural teaching are also successfully used for assessment: culture assimilators and critical incidents, culture capsules and clusters, portfolios, report writing, role play, essay writing, peer assessment, simulations, self-evaluation, comparison-contrast method, cultural mini dramas, checklists, interviews in reflective formats, questionnaires, journals, etc. These tools exemplify best practices in intercultural instruction and are built upon the theoretical frameworks delineated in this study. These learning and teaching tasks assist learners and teachers in building interculturality within the context of the L2 classroom. 


\subsection{CRITICAL INCIDENTS AS INTERCULTURAL TRAINING AND ASSESSMENT TOOLS}

Since their first use by Flanagan in 1954 to investigate effective and ineffective job behaviour, critical incidents have become an unavoidable tool in the professional intercultural development context to increase intercultural understanding and handling of cross-cultural situations. Many researchers and practitioners emphasise the usefulness of critical incidents in intercultural instruction, especially in understanding intercultural interactions (Apedaile and Schill 2008; Bhawuk 2001; Corbett 2003; Kiliańska-Przybyło 2017; Lazarević 2013; Spencer-Oatey 2013; Spencer-Oatey and Franklin 2009). Critical incidents are based on experiential-learning methodology and represent "...brief descriptions of situations in which a misunderstanding, problem or conflict arises as a result of the cultural differences of the interacting parties, or a problem of cross-cultural adaptation and communication" (Apedaile and Schill 2008, 7). Woods (2012, 1) defines them as: "...highly charged moments and episodes that have enormous consequences for personal change and development". Each incident or a story clearly and concisely sets the scene and describes what has happened, frequently revealing the feelings and reactions of those involved in it. The incident does not explain the cultural differences between the participants or culturally motivated values, norms and behaviours. The learners are invited to discuss the possible reasons of the misunderstanding. It is the absence of the interpretations to choose from that encourages the learners to suggest their own ways of handling the situation. Therefore, the incident is open to multiple interpretations and it represents "a rich vein for exploring the development of critical thinking and problemsolving skills" (McAllister et al. 2006, 371, as cited in Lazarević 2013, 107). Crosscultural dialogues are in essence critical incidents in a dialogue form. When they are properly constructed and presented to L2 learners, they can be skillfully exploited to instill knowledge about cultures and help to develop openness, flexibility and empathy (Storti 1999). A technique similar to critical incidents is the "cultural assimilator", which is a programmed learning package consisting of a number of critical incidents (Cushner and Brislin 1996). Unlike a critical incident, a cultural assimilator describes an incident and is followed by four or five possible explanations (Triandis 1975, 1995). In a cultural assimilator, learners are expected to choose the "best" or the "most appropriate" or plausible explanation context-wise.

Both cultural assimilators and critical incidents are extensively researched, theoretically founded and based on the psychological principles to reinforce the learning process. What makes these critical scenarios or episodes critical is actually the significance of the incidents in the daily life of the individuals and the necessity of their implementation in cross-cultural training programmes (Bhawuk 2001, 143). For some other authors criticality refers to the informative content and the explanatory role of critical incidents (Webster and Mertova 2007; Woods 2012). Wight (1995, 128-129) clearly explained that the purpose of critical incidents was to confront the learners with conflicting, confusing or frustrating situations that they can expect to encounter while interacting with persons from another culture, or while adjusting to a new culture. Critical incidents have many values in the intercultural field, most of which have been insightfully identified by Wight $(1995,128)$. Through critical incidents L2 learners should: (a) increase awareness of their own and others' behaviour, attitudes and responses in potentially conflicting situations, (b) critically analyse various interpretations and perceptions of the participants, (c) clarify the cultural differences that might have provoked misunderstandings, problems or conflicts, (d) understand the diversity among 
members of each culture being dealt with, (e) acquire understanding necessary to behave more appropriately and effectively in similar situations, (f) increase the participants' awareness of the things they need to learn and motivate them to continue learning, $(\mathrm{g})$ provide a solid basis for engaging in role plays that will develop their skills to handle various cross-cultural situations (Wight 1995, 128-129). Critical incidents empower learners to derive meaning, to cultivate much-needed empathy and find commonalities with culturally different people, and that is why we have decided to exploit these intercultural training tools for the purposes of our research study.

\section{METHODOLOGY}

This research study was designed to explore the intercultural sensitivity and competence of EFL majors at the Department of English Studies of the Faculty of Philosophy, University of Novi Sad. It set out to prove the following hypothesis: EFL majors possess intercultural sensitivity and competence to resolve possibly controversial intercultural situations presented through critical incidents. It is hypothesised that the respondents will have an ethnorelative/ intercultural perspective and will exhibit openness, emotional empathy and understanding of different cultural and behavioural patterns. They are expected to be aware of cultural differences and to be competent enough to find out the underlying motives of potentially conflicting situations, and ultimately solve them in a culturally appropriate manner.

\subsection{Participants}

The participants of this study were third and fourth-year English majors, and a total of $142(\mathrm{~N}=142)$ respondents participated in this study. Of the whole sample, seventy-eight $(\mathrm{N}=78)$ were third-year, and sixty-four were fourth-year students $(\mathrm{N}=64)$. The sample of students included both female (third year: $\mathrm{N}=68$; fourth year: $\mathrm{N}=56$ ) and male students (third year: $\mathrm{N}=10$; fourth year: $\mathrm{N}=8$ ), which reflects the general gender distribution of this study group. The average age of third-year students was 21.46, and of fourth-year students, it was 22.44. Apart from the basic demographic data, some other background information was also gathered that could help contextualise the research results. Specifically, of the whole sample of respondents 128 informants $(90.14 \%)$ spoke Serbian as their mother tongue, while the rest reported that they spoke Hungarian, Slovak, Ruthenian, Croatian, and Spanish (spoken by a Spanish Erasmus + fourth-year student).

Table 1 Participants' mother tongue

\begin{tabular}{lrllrr}
\hline Mother tongue & 3. year $(\%)$ & Mother tongue & \multicolumn{2}{c}{ 4. year (\%) } \\
\hline Serbian & 72 & $(92.3 \%)$ & Serbian & 56 & $(87.5 \%)$ \\
Hungarian & 3 & $(3.8 \%)$ & Hungarian & 5 & $(7.8 \%)$ \\
Slovak & 2 & $(2.6)$ & Slovak & 1 & $(1.6 \%)$ \\
Ruthenian & 1 & $(1.3 \%)$ & Croatian & 1 & $(1.6 \%)$ \\
& & & Spanish (Erasmus+) & 1 & $(1.6 \%)$ \\
\hline
\end{tabular}


When asked what other foreign languages, apart from English, the students spoke, they claimed they had active or passive knowledge of at least one other foreign language (see Table 2 below):

Table 2 Other foreign languages spoken besides English

\begin{tabular}{lrllr}
\hline Other foreign languages spoken & $3^{\text {rd }}$ year $(\%)$ & Other foreign languages spoken & $4^{\text {th }}$ year $(\%)$ \\
\hline No other foreign language & $7(9.00 \%)$ & No other foreign language & $11(17.2 \%)$ \\
One more foreign language & $44(56.4 \%)$ & One more foreign language & $27(42.2 \%)$ \\
Two more foreign languages & $21(26.9 \%)$ & Two more foreign languages & $18(28.1 \%)$ \\
Three more foreign languages & $5(6.4 \%)$ & Three more foreign languages & $5(7.8 \%)$ \\
Four more foreign languages & $1(1.3 \%)$ & Four more foreign languages & $3 \quad(4.7 \%)$ \\
\hline
\end{tabular}

Students are aware of the importance of proficiency in other languages other than English, which is in line with the requirements of modern language pedagogy and global citizenship. The languages the respondents speak include German, Spanish, Russian, Hungarian, Slovakian, Italian, Greek, French, Serbian, Dutch, Ukrainian, Chinese, Norwegian, Portuguese, Japanese, Korean, Hebrew, Romanian, Ruthenian, Czech, Finnish, and Turkish.

\subsection{Instrument}

The purposely designed open-ended questionnaire used in this research comprised two parts: the first part consisted of three general questions concerning demographic variables and personal background data, and the second part encompassed five critical incidents (CI). More precisely, out of five critical episodes, only three (CI: 3, 4, 5) were adapted from the cultural assimilator given in Lazarevic $(2013,2017)$, who is one of the leading researchers in the intercultural field in Serbia. However, all the cultural scenarios never included attributions or solutions, just a short story or a dilemma situation, followed by questions to get the participants to imagine being part of these episodes. The intention of such a concept was primarily to enable the respondents to exhibit all the possible behavioural patterns or explanations for different culturally motivated values and norms. By using a qualitative content analysis, the core meanings or patterns of the students' beliefs were inductively identified and classified into corresponding themes or categories. Whenever it was possible and desirable, the frequency of code or category occurrence was measured. The questionnaire was anonymous, which only contributed to the validity of the study as students gave comprehensive and honest answers.

\subsection{Procedure}

The students were given a maximum of forty-five minutes to complete the questionnaire, which was administered within regular ELT Methodology practice classes in the third year and English Language Teaching Methodology - Teaching Practicum classes in the fourth year of English Studies, in May 2018 and 2019. All the students gave consent for the participation in the research. They were informed by the researcher that their responses would remain confidential and were instructed to be as clear and open as possible, which was essential to the validity and success of the research study. As was previously mentioned, qualitative data analysis was conducted in order to gain a deeper insight and a better understanding of the students' perspectives pertaining to intercultural issues. Wherever it was possible, the recurrent patterns or themes obtained from the qualitative data were supported by descriptive statistics. 


\section{RESULTS AND DISCUSSION}

The aim of the study is to explore whether the participants possess positive attitudes towards potentially conflicting cultural episodes, which will provide reasonable evidence that participants are interculturally sensitive and competent. In the first, general question, the participants were asked whether they had ever travelled abroad, how long and for what purpose. Of the entire sample, only four students $(2.8 \%)$ had never travelled abroad, only one student $(0.7 \%)$ had been living in Australia for nine years, and all the rest travelled all around the globe for various reasons: for tourist purposes/recreational purposes (getting to know more about specific countries and their cultures, as they stated; Work-and-Travel programmes, sports competitions, visiting relatives...), for instruction/educational reasons (intercultural exchanges of youth activists, International Youth Mathematician Euromath Conferences, Eastern Generative Grammar Summer Schools, summer and winter language schools, summer and winter camps on tolerance, Erasmus+ mobility exchange programmes, exchange programmes in secondary schools...), for work purposes (Work-and-Travel programmes, aupair scheme, translating...). The length of their stays varied from a minimum of two weeks to a maximum of one year. The range of countries the participants reported they had visited for various reasons was impressive: Hungary, Slovenia, USA, Greece, Austria, Slovakia, Switzerland, Germany, Montenegro, Czech Republic, Portugal, France, Italy, UK, Turkey, Romania, Poland, Cyprus, Malta, Tunisia, Canada, Spain, Croatia, Bosnia and Herzegovina, Ukraine, Malaysia, Dominican Republic, Japan, China, Sweden, United Arab Emirates, Ireland, Bulgaria, Iceland, Albania, The Netherlands and Belgium.

When asked whether they had ever visited an English-speaking country, (Q2) 114 students $(80.3 \%)$ reported they had not had an opportunity to visit any of them. The remaining $19.7 \%$ of the students had visited the USA, England, Northern Ireland, Wales, Canada and Australia, mostly for educational (summer language courses, exchange programmes...), tourist/recreational purposes and work purposes. Although a large number of students claimed to have travelled abroad, only a certain number of them had had the opportunity to visit English-speaking countries to practise their English and gain deeper cultural insights. One student honestly remarked (all the answers in the survey are cited verbatim):

S (student) 6: Unfortunately, I never had the chance to visit an English-speaking country, but it has always been one of my greatest desires to visit England.

In Question 3, "Do you have foreign friends abroad and do you keep in touch with them?" thirty-nine students $(27.5 \%)$ admitted they did not have any foreign friends abroad, while the rest of the sample claimed to have had them in the following countries: Belarus, Lithuania, Kenya, Venezuela, Peru, Russia, Ukraine, Finland, Singapore, The Netherlands, Kyrgyzstan, Morocco, Jamaica, Cyprus, USA (Native Americans - Shawnee), Czech Republic, Australia, Italy, Spain, Poland, Sweden, Belgium, UK, Greece, Japan and Germany. The participants reported that they regularly talked to their friends in English via social networks and video calls: Skype, WhatsApp, Viber, Facebook, email... In the students' own words, modern technology makes their communication so much easier, so they can communicate with their foreign friends, help each other out with many issues, play video games and spend a lot of time with them when they come to Serbia. Indeed, these new technological tools facilitate and improve one-to-one, one-to-many and many-to-many communication and collaboration, and are undoubtedly a constituent part of people's lives. 
The second part of the questionnaire comprises cultural episodes whose purpose was to investigate the participants' frames of reference regarding disconcerting or controversial occurrences. Hence, in Question 4 (CI 1) students were asked to imagine themselves in a restaurant in London, and that the waiter had made a mistake with their order and so they were asked what they would say or do. After a detailed analysis of the students' responses, two broad categories were identified:

Table 3 Critical incident 1

\begin{tabular}{lc}
\hline Categories & No. of references (\%) \\
\hline a) Ss would politely apologise and ask for the right order. & $99(69.7 \%)$ \\
b) Ss would politely accept the wrong order without a word. & $43(30.3 \%)$ \\
\hline
\end{tabular}

As can be seen from the Table 3, the majority of students $(69.7 \%)$ said that they would politely apologise for having to inconvenience the waiter and would clarify there had been a mix-up with their order, and consequently politely repeat the right order and thank him/her. The students' reactions were manifested through their careful phrasing and communicative signals/indicators that reflected their comprehension of the mistake, their sympathy, and good intentions. Therefore, students used words such as: politely, kindly, tactfully, nicely, silently, calmly, etc. to show their appreciation, and also verbal expressions such as: Excuse me, Sir, ...; Sorry to trouble you...; Would you mind ... and thank you!; I beg your pardon, Sir,...; Could you please...? Respondents substantiated their answers by saying that: they would not cause any inconveniences as it is a natural occurrence in such a big niche as food service; they would politely ask for the right meal but would pay for both orders because everyone can make a mistake; they would definitely find an appropriate way to explain the mistake in their order especially if they got a more expensive meal, etc. Some of the answers were as follows:

S1: I would politely apologise and ask whether there has been a misunderstanding and then explain what I have ordered, and sincerely hope we would be able to resolve the issue.

S94: I would ask the waiter when I see that they are not busy with other customers, and I would politely point out that they had made a mistake. Then I would ask for my order to be replaced, something like: "Excuse me, but I think you have made a mistake in my order. I ordered XXX. Could you please replace it? Thank you!"

As for those $30.3 \%$ of respondents who would politely accept the wrong order without a word, they justified their answers by claiming that: they would not mind as long as they can eat it or drink it; they would pretend it did not happen; they would not do anything to humiliate the waiter; they would not mind much because everyone makes mistakes; mistakes happen and there is really no need to be mean about it; waiters can get into trouble when they make a mistake, so they would feel sorry for them especially if they are nice and pleasant; they love trying new things, etc. as can be seen in some of their comments:

S41: I would just settle for what was originally mistakenly given. I would not make a scene, start an argument, or ask to talk to the manager. 
S47: I would not say anything unless I am really allergic to the food or strongly dislike it. Only in that case would I politely and calmly inform the waiter of the mistake. Otherwise, I would not make a big deal out of it.

Qualitative analysis of their answers leads us to the conclusion that there exists a high degree of open-mindedness, flexibility, empathy and respect for others in the target culture, which is supported by their actions and linguistic evidence in the form of formulaic speech and other communicative indicators characteristic of British courtesy (Fox 2014). In the same vein, with Question 5 (CI 2) we wanted to find out what their attitudes and values were in the situation where had to imagine themselves studying at a British university and they were late for the exam. They were asked what they would say or do. Three categories of answers were identified.

Table 4 Critical incident 2

\begin{tabular}{lc}
\hline Categories & No. of references (\%) \\
\hline a) Ss would politely apologise telling the truth and hoping to be able to & $135(95.1 \%)$ \\
take the exam. & $2(1.4 \%)$ \\
b) Ss would not say anything but take their seat and do the exam. & $5(3.5 \%)$ \\
c) Ss would not dare take the exam. &
\end{tabular}

In the first category, there were 135 students $(95.1 \%)$ who would politely apologise, tell the truth as to why they were late and hope to be allowed to take the exam. For them "being late is rude and irresponsible", so if it happened there must have been a serious or valid reason for their being late. As they said, they would act as politely as possible, walking up to the professor as quietly as possible so as not to disturb their fellow students, and very politely and quietly apologise. If the professor allowed them to take the exam, they would thank him/her after the exam for the given opportunity; if not, they would leave the room and wait for the exam to finish and ask the professor for advice. All the students unanimously claimed they would never lie about the reasons for being late as "honesty is the best policy", and moreover, they know that British professors are very strict when it comes to being on time, so they commented:

S38: I have never been late or very late for any exam during my studies but if it ever happened, I suppose there would have to be a valid reason for my being late. I would try to explain what happened using as few words as possible and ask the professor if I could take the exam. If s/he rejected my request, I would silently leave the room, feeling very humiliated because it was my fault.

S141: I have been told by several British people that they consider being late as a sign of disrespect and that the person being late always gets those horrible judgmental looks, so I would probably really nervously apologise like crazy hoping the professor accepts my apology.

Being on time for exams is a universally recognised academic convention. In Western countries, being late without a legitimate reason is considered bad manners. The British place a high value on punctuality, therefore being late for such an important occasion as an examination is unacceptable and may cause serious trouble. The respondents in this survey were well aware of this cultural expectation, so the language forms they used were 
contextually appropriate, embodying the values and meanings the British people cherish. To illustrate, they used the following communication patterns: Would it be possible for me to still take the exam? May I please take the exam? Excuse me, Sir, may I please take the exam? Is there any chance I could attend the exam? and the like. They also claimed they would honestly / deeply / kindly / sincerely / politely / profusely / profoundly / quietly apologise or say they are terribly sorry, very sorry, really sorry, etc.

Of the total sample of respondents, $1.4 \%$ would not say anything in order not to disturb their colleagues, but would rather find the first empty seat and wait for the professor to give them the test. Only if the professor said something first, would they respond appropriately while managing a high level of stress and anxiety. And 3.5\% of respondents admitted they would not have the audacity to be very late for the exam and would not even dare take it. In Question 5, (CI 3, adapted from Lazarević $(2013,283$; 2017, 23) students were asked:

Marko from Serbia arrived at an American university and started going to classes. However, he was very disappointed to see the way students behaved in class. They would take off their shoes, put up their feet on the seat in front of them, would be laid back. What surprised Marko even more is the fact that teachers didn't mind this at all. There was one instance when a young man, sitting back, with his feet up, raised his hand and asked for a clarification, and the teacher calmly provided one. Marko couldn't understand this at all.

a) What do you think led to the occurrence of this problem?

b) What advice would you give to Marko?

As can be seen in the Table 5 below, the vast majority of students $(73.2 \%)$ explained that Marko's shock was due to the mismatch between different cultural and behavioural patterns or expectations in an academic milieu. Respondents did not make any negative value judgments personally, nor did they depict this kind of behaviour in the negative light. They unambiguously pointed out that Marko comes from a different cultural background which is more traditionally oriented and where this kind of behaviour would be considered rude, or inappropriate, unacceptable or disrespectful. They notice that Marco is having a hard time getting used to the behaviour of his fellow students because he probably never saw students acting in this way in his native country. Therefore, not being exposed to and not knowing about other, different foreign cultures can easily lead to such problems and can cause a misunderstanding of what is socially and culturally (un)acceptable. However, they agree that they cannot judge a culture or cultural practice just because it is different from what they are used to. For them, Marko lacks knowledge about the American culture, that is to say he is not "culturally aware nor did he do any research about the culture or university". Some participants also noticed that Marko was not used to the absence of "large power distance", which is characteristic of societies whose members accept a hierarchical order to be respected (Lazarević 2017, 25). So, the respondents said:

S10: Marko was not used to such a laid-back atmosphere, since schools and universities in Serbia are much more formal and such behaviour would be considered very rude, which was obviously not the case here. By the way, I had a teacher in England who would take off her high heels and walk around the classroom barefoot. Thankfully, there were carpets in the classrooms $;$. 
S16: This is something one could rarely see at Serbian universities. Still, if the person sitting back with his feet up is not in any way disturbing the lecture, while being active and involved, how he is sitting should not matter.

S26: The different expectations regarding the students' behaviour - things are typically much more rigid in Serbia. Marko's shock is due to the fact that this sort of thing is considered incredibly disrespectful in his native country.

Table 5 Critical incident 3

\begin{tabular}{lc}
\hline Categories & No. of references $(\%)$ \\
\hline a) cultural differences & $104(73.2 \%)$ \\
b) not a real problem & $17(12.0 \%)$ \\
c) lack of classroom management skills & $21(14.8 \%)$ \\
\hline
\end{tabular}

Of the total sample, $12 \%$ of respondents explicitly said that such a behaviour was not really a problem, that he was just confused because he does not know the customs and that he just needs to get used to the culture, to be assimilated:

S119: This is not a problem. Marko's "disappointment" is due to his own expectation that another culture should have the same standards of behaviour as his own. Such a laid-back attitude is common in America and neither the teachers nor the students perceive it as, nor intend it to be, disrespectful. If Marko "couldn't understand this at all", he needed only ask for clarification.

In addition, $14.8 \%$ of the surveyed students attributed such behaviour to the professor's lack of classroom management skills, claiming he did not have authority, strictness and good control over the class, and did not state any rules regarding discipline. Some stated that "the professor probably told the students to make themselves as comfortable as they like so that they could enjoy the class". When asked what advice they would give to Marko they responded that:

- Marko should immerse himself into their culture, embrace it without judging it,

- he should enjoy this cultural experience because it is invaluable,

- he should familiarise himself with the customs, people and their values; it is important to be open-minded, to bond with the American people, explore the world around him and try to be part of their culture,

- he should accept it as a simple cultural difference and understand that just because the environment is different, it does not mean it is bad or wrong; he should think about how this atmosphere could benefit the class; if he really feels uncomfortable he should talk to his classmates and understand why they act the way they do,

- he should observe the behaviour of American students and accept the social norm that is in place at that university...

S10: I would advise Marko to accept the fact that this is simply a cultural difference that exists between Serbia and the USA. However, he should not follow in the other students' footsteps just to fit in, if that makes him uncomfortable. As a matter of fact, coming from the more formal education system in Serbia, I was always considered to be very polite by my teachers, both in England and in Spain (e.g. I would use 'usted', the more formal 
variant of the $2^{\text {nd }}$ person pronoun, which most students don't use when talking to their teachers, but they seemed to appreciate it.).",

Overall, by objectively recognising different cultural patterns and practices the students seem to be at the far end of the ethnocentric stage (minimisation) and at the beginning of the ethnorelative stage (acceptance), whereby both Serbian and American cultures are appreciated as valid cultures.

In Question 6 (CI 4, adapted from Lazarević (2013, 293; 2017, 98) students were given the following scenario to study and say how they felt and what they would do:

You, the only native Serbian speaker, are spending three weeks in a summer camp in Austria. Currently, you are on a lunch break talking to newly-met students, when a small group walks in, speaking a language you do not understand, and seems to be having fun. You look around and sure enough, within earshot, there is another group already seated and speaking yet another different language.

a) How do you feel?

b) What would your feelings be if you overheard your name in the middle of one of the conversations and would you react in any way?

Two broad categories of emotions were identified:

Table 6 Critical incident 4

\begin{tabular}{lc}
\hline Categories & No. of references $(\%)$ \\
\hline a) Ss feel motivated and interested & $87(61.3 \%)$ \\
b) Ss feel uncomfortable and left out & $55(38.7 \%)$ \\
\hline
\end{tabular}

More than half of the respondents $(61.3 \%)$ say they feel happy because they are in a multinational setting, "in such a diverse background, among so many different people" where they have the opportunity to hear and experience other languages and see them used authentically. They see this situation as an opportunity to tell the others in the camp something about their Serbian culture, to make new friends and find out which languages these are. They say they would feel excited and fascinated by all the variety around them and that they "...would find a way to communicate even if we do not speak the same language, it is not an obstacle as long as both sides are friendly and willing to communicate".

S83: I feel OK because it is normal for students who speak the same language to stick together at first. I'm sure that there will be numerous opportunities to meet all of them and get to know them.

The participants used a whole range of adjectives to describe their emotions: OK, special, great, excited, comfortable, cool, good, happy, motivated, curious, fascinated, delighted, normal, exhilarated, international, nice, amused, etc. Still, there were $38.7 \%$ of the participants who expressed feelings of discomfort and isolation in such an environment, and stated they would feel: confused, annoyed, uneasy, like an outsider, ashamed, lonely, excluded, insecure, isolated, unwanted, anxious, irritated, left out, discriminated against, homesick, awkward, indifferent, ignored, sad, disappointed, unwelcome, strange, rejected, 
nervous, neglected, etc. However, most of the participants who expressed the presence of negative emotions stated clearly and firmly that they would do something about it.

S47: Probably a bit irritated if they all know English; speaking another language in front of a person who does not speak it is impolite.

S78: Probably left out but I can understand that people find it easier to talk to others who share the same language. I would approach one of the groups and ask to join them.

When asked: "What would your feelings be if you overheard your name in the middle of one of the conversations and would you react in any way?" they responded in the following way:

Table 7 Critical incident 4

\begin{tabular}{lc}
\hline Categories & No. of references $(\%)$ \\
\hline a) Ss would not mind at all. & $94(66.2 \%)$ \\
b) Ss would feel uncomfortable just for a moment. & $24(16.9 \%)$ \\
c) Ss would feel very uncomfortable assuming something negative. & $24(16.9 \%)$ \\
\hline
\end{tabular}

The majority of respondents $66.2 \%$ claimed that they would not put much thought into it even if the groups were talking about them, because it does not mean it was necessarily bad; then they would presume that they were mentioned in a positive context; that they would be surprised and curious but would have no prejudices; some would wave to them, come over and introduce themselves - if the group seemed friendly; some students would just look in the direction to see if someone from the group might be calling for them, and if not they would continue doing their own thing...

S141: I would not do anything. I have been in situations like that before and from what I have learned, whenever you hear a language you do not know you almost automatically assume that you are the topic of their conversation and that is almost never the case. So, unless I am 100\% sure they are talking about me specifically I would take no actions. Even if I find out they are talking about me, I don't think I would do anything.

The remaining $33.8 \%$ of the students would feel uncomfortable just for a moment or very uncomfortable. They specified that they would be intrigued as to why their name was mentioned and would automatically assume it was used in a negative context. However, the respondents claimed they would not react at all, although "it would hurt their self-confidence".

S103: I would feel uncomfortable because I would not understand why they were mentioning me. I would probably not react in any way at that moment, but if I thought they were making fun of me, I would ask the group about it later.

Indeed, these students' reactions were part of normal cognitive functioning because people tend to rely on what they think they know or what they have heard (which is not necessarily true) in order to pass judgment or reach a decision (Lazarević 2017, 99). This may be an easy route to forming stereotypes or misleading overgeneralisations, ultimately leading to miscommunication. 
In the last Question 7 (CI 5), the respondents were asked the following (Lazarević 2013, 292; 2017, 145):

Jane, an American, has been in Serbia for two months; she's in her 30s and has been working with a local NGO. She met a lot of people of different ages, occupations and social status. There is one thing that she finds strange, and that is when people keep asking her questions about her private life, salary and family. Jane feels uncomfortable because she's not used to such questions.

a) How would you explain this to Jane?

b) What advice would you give to Jane?

All the respondents unanimously agree that this is a matter of cultural differences. More precisely, they say that would explain to Jane: that this is part of the Serbian culture, our mentality or way of thinking; then that these kinds of culture-specific questions are not intended as an insult, but more like casual small-talk between people who were trying to connect with her on a more personal level; that the Serbs (as open and direct people) were not trying to be malicious, rude or disrespectful but friendly and accepting. There were observations that the Serbs are much more direct than Americans and do not have the same social boundaries or inhibitions about what is appropriate. The respondents were quite critical of their native culture claiming that Serbs are family-centric and nosy by nature, and asking about one's salary is actually "curiosity about the profession/niche, not her own personal finances". Some even remarked that it is the elderly people who tend to ask such personal questions, and that the young are far less likely to do so. The analysis of the responses point to the fact that although there were some "us" and "them" polarisations revealing the ethnocentric outlook, respondents predominantly distanced themselves form the Serbian cultural framework or their own cultural frame of reference:

S26: I would most likely fail at about 70\% of it. While I'm generally fine with basic questions about family as a way of making conversation, those about private life and salary instantly tick me off. I find them exceedingly difficult to even borderline tolerate, and tend to slam those doors firmly shut for anyone not explicitly invited through them; so even though the Serbian culture is my native, Jane and I would be stuck in the same situation.

When asked what advice they would give to Jane, only 11 students (7.7\%) of the total sample responded that they would advise Jane to adapt to Serbian customs; keep an open mind and that she would soon get accustomed to the Serbian culture and not feel left out. They would also advise her to open up gradually, "go with the flow" as "telling someone a little bit of something about oneself can lead to new friendships;

S18: I'd tell her it is perfectly fine if she doesn't feel like answering these questions, but at the same time I'd advise her to try to blend in and get used to our people if she plans on staying here, since at the end of the day they mean no harm, they are simply curious.

The remaining 131 students (92.3\%) empathise with Jane due to evident cultural differences. The respondents advise Jane that it is up to her whether to answer or not, and not to take it personally or give it much thought as these questions are not intended as an insult. They also advise her to tell her Serbian friends that she is not accustomed to being asked such questions and that she feels she honestly cannot share her personal life with others; that she can change 
the topic of the conversation by mentioning the cultural differences and how interesting they are; that she can smile politely and avoid answering the questions...

S23: I would advise Jane to let go of feeling uncomfortable and try to understand that this kind of behavior is perfectly normal and understandable in a Serbian cultural setting. That being said, she must not feel forced into answering questions that seem too intimate or personal for her to discuss with others.

The respondents showed a heightened awareness of their own cultural values and objectively and honestly explained to Jane, an American, what she should do to overcome her discomfort and potential misunderstandings. By empathising with her, they actually paved the way to tolerance and patience, recognition and appreciation of cultural differences.

\section{CONCLUSION}

The research reported in this paper looked into issues concerning the intercultural awareness and sensitivity of EFL majors. The results obtained by using a qualitative critical incident technique confirmed the initial hypothesis: the respondents possess an intercultural perspective or ethnorelative worldview as they exhibited empathetic and positive attitudes, openness, respect, adaptability, flexibility and curiosity in potentially controversial intercultural encounters. They were appreciative and aware of different cultural practices, not once perceiving their native culture as better or superior. The respondents' demonstrated emotional empathy could have a positive impact on their intercultural sensitivity and competence. However, more definitive conclusions might be drawn from a longitudinal study or the triangulation of data. Mixed method research involving both qualitative (critical incident analysis and interviews) and quantitative research methodology (questionnaires) would undoubtedly give a deeper and better empirical insight into the complex issue of intercultural communicative competence.

A potential contribution of the study may be best recognised in the practical implications that follow from this critical incident analysis, which is a practically oriented and efficient research method used to identify potential causes of problems in intercultural encounters. Critical incidents represent one of the many pedagogical tools which engage participants in self-reflection, they develop the students' critical selfawareness and understanding, and assess the level of attained intercultural competence. Fine-tuned incidents can be successfully used at all stages of intercultural learning and with students of different ages and fields of study. The mere fact that this research study was undertaken with EFL university students makes it even more meaningful, because it is these students who will be future language educators or will work in areas demanding adequate linguistic and intercultural competence. In the end, we are left with the conclusion that the development of intercultural sensitivity and competence should be an integral part of general education, all for the purpose of educating students as global citizens - devoid of stereotypes and ethnocentrism. 


\section{REFERENCES}

Apedaile, Sarah, and Lenina Schill. 2008. Critical Incidents for Intercultural Communication. An Interactive Tool for Developing Awareness, Knowledge, and Skills. Edmonton, Alberta: NorQuest College.

Atkinson, Dwight. 1999. “TESOL and Culture.” TESOL Quarterly, Vol. 33: 625-654.

Bandura, Ewa. 2011. "Developing Cultural Self-Awareness and Knowledge to Enhance Intercultural Competence of Foreign Language Students." In A. Niżegorodcew, Y. Bystrov, and M. Kleban, (Eds.), Developing Intercultural Competence through English: Focus on Ukrainian and Polish Cultures, 45-56. Kraków: Jagiellonian University Press.

Bennett, Milton J. 1993. "Towards Ethnorelativism: A Developmental Model of Intercultural Sensitivity (revised).” In R. M. Paige (Ed.), Education for the Intercultural Experience, 21-71, Yarmouth, Me: Intercultural Press.

Bennett, Milton J. 2011. A Developmental Model of Intercultural Sensitivity. Milano: The Intercultural Development Research Institute.

Bennett, Janet Marie and Milton J. Bennett. 2004. "Developing Intercultural Sensitivity: An Integrative Approach to Global and Domestic Diversity." In D. Landis, J. M. Bennett and M. J. Bennett (Eds.), Handbook of Intercultural Training, 3rd ed, 147-165, Thousand Oaks, CA: Sage.

Bhawuk, Dharm. 2001. "Evolution of Culture Assimilators: Toward theory-based assimilators." International Journal of Intercultural Relations 25 (2001): 141-163.

Bhawuk, Dharm, and Richard Brislin. 1992. "The Measurement of Intercultural Sensitivity Using the Concepts of Individualism and Collectivism." International Journal of Intercultural Relations, 16 (4): 413-36.

Breunig, Karl, and Line Christoffersen. 2016. "If x, then why? Comparative Analysis Using Critical Incidents Technique." Journal of Business Research 69 (11): 5141-5146.

Butterfield, Lee, William, Borgen, Norman Amundson, and Asa-Sophia Maglio. 2005. "Fifty Years of the Critical Incident Technique: 1954-2004 and Beyond." Qualitative Research 5(4): 475-497.

Byram, Michael. 1997. Teaching and Assessing Intercultural Communicative Competence. Clevedon, England: Multilingual Matters.

Byram, Michael. 2000. "Assessing Intercultural Competence in Language Teaching." Sprogforum 18 (6): 8-13.

Chen, Guo-Ming. 2010. Study on Chinese Communication Behaviors. Hong Kong, China: China Review Academic Publishers.

Chen, Guo-Ming, and William Starosta. 2004. "Communication among Cultural Diversities: A Dialogue." In GM. Chen and W. Starosta (Eds.), Dialogue among diversities, 3-15, Washington, DC: National Communication Association.

Chen, Guo-Ming, and Priscella Young. 2012. "Intercultural Communication Competence." In A. Goodboy and K. Shultz (Eds.), Introduction to Communication: Translating Scholarship into Meaningful Practice, 175188. Dubuque, IA: Kendall-Hunt.

Cohen, Louis, Lawrence Manion and Keith Morrison. 2007. Research Methods in Education. London and New York: Routledge.

Common European Framework of Reference for Languages: Learning, Teaching, Assessment. 2001. Strasbourg: Council of Europe; Cambridge: Cambridge University Press.

Common European Framework of Reference for Languages: Learning, Teaching, Assessment. Companion Volume with New Descriptors. 2018. Strasbourg: Council of Europe.

Corbett, John. 2003. An Intercultural Approach to English Language Teaching. Clevedon: Multilingual Matters Ltd.

Cushner, Kenneth. 2014. "Strategies for Enhancing Intercultural Competence across the Teacher Education Curriculum.” In J. Phillion, S. Sharma, and J. Rahatzad (Eds.), Internationalizing Teacher Education for Social Justice: Theory, Research, and Practice, 139-162. Charlotte, NC: Information Age Publishing, Inc.

Cushner, Kenneth. 2015. "The Development of Intercultural Competence in Teachers and Students." In N. Lazarević, M. Savić, T. Paunović, and Lj. Marković (Eds.), Teaching Languages and Cultures in the PostMethod Era: Issues and Developments, 3-13, Niš: Faculty of Philosophy.

Cushner, Kenneth, and Richard Brislin. 1996. Intercultural Interactions: A Practical Guide. Thousand Oaks: Sage.

Deardorff, Darla K. 2006. "Identification and Assessment of Intercultural Competence as a Student Outcome of Internationalization." Journal of Studies in Intercultural Education 10: 241-266.

Fox, Kate. 2014. Watching the English. London: Hodder \& Stoughton Ltd.

Furstenberg, Gilberte. 2010. "Making Culture the Core of the Language Class: Can It Be Done?" The Modern Language Journal, 94 (2): 329-332.

Hammer, Mitchell R. 2011. "Additional cross-cultural validity testing of the Intercultural Development Inventory." International Journal of Intercultural Relations, V35: 474-487.

Hammer, Mitchell R., Milton J. Bennett, and Richard Wiseman. 2003. "Measuring Intercultural Sensitivity: The Intercultural Development Inventory." International Journal of Intercultural Relations, 27 (4): 421443. https://doi.org/10.1016/S0147-1767(03)00032-4. 
Ho, Si Thang Kiet. 2009. "Addressing Culture in EFL Classrooms: The Challenge of Shifting from a Traditional to an Intercultural Stance.” Electronic Journal of Foreign Language Teaching, Vol. 6, No. 1: 63-76.

Huitt, William. 2020. "Multiculturalism: Can We Talk?" Ordinary Times, January 6, 2020.

Kiliańska-Przybyło, Grażyna. 2017. The Anatomy of Intercultural Encounters. A Sociolinguistic Cross-Cultural Study. Katowice: Wydawnictwo Uniwersytetu Śląskiego.

Lazarević, Nina. 2009. "Do We Teach Teachers to Teach Culture?" U Jezici i kulture u kontaktu, Zbornik radova, 404-412. Podgorica: Institut za strane jezike.

Lazarević, Nina. 2013. "Intercultural Competence as an Aspect of the Communicative Competence in the Tertiary Level English Language Learners." PhD diss., Faculty of Philosophy, University of Novi Sad.

Lazarević, Nina. 2017. Intercultural Communicative Competence: how to get there. Niš: Faculty of Philosophy.

Lazarević, Nina. 2018. "Assessment of Intercultural Communicative Competence in Pre-Service English Language Teachers: Challenges and Practices.” Nastava i vaspitanje, Br. 3: 471-487.

Liddicoat, Anthony, and Angela Scarino. 2013. Intercultural Language Teaching and Learning. Chichester: Wiley-Blackwell.

Mahon, Jennifer. 2006. "Under the invisibility cloak? Teacher understanding of cultural difference." Intercultural Education 17 (4): 391-405.

McAllister, Lindy, Gail Whiteford, Bob Hill, Noel Thomas, and Maureen Fitzgerald (2006). "Reflection in Intercultural Learning: Examining the International Experience through a Critical Incident Approach." Reflective Practice, 7 (3): 367-381.

Méndez García, Maria del Carmen. 2016. "Intercultural Reflection through the Autobiography of Intercultural Encounters: Students' Accounts of their Images of Alterity." Language and Intercultural Communication 17 (2): 90-117.

Micó-Cebrián, Paula, and María-Jesús Cava, M., 2014. "Intercultural sensitivity, empathy, self-concept and satisfaction with life in primary school students.” Infancia Y Aprendizaje, 37 (2): 342-367.

Moeller, Aleidine Kramer, and Kristen Nugent. 2014. "Building Intercultural Competence in the Language Classroom.” In Unlock the Gateway to Communication, edited by Stephanie Dhonau, 1-18. Eau Clarie, WI: Crown Prints.

Moloney, Robin and Lesley Harbon. 2010. "Making Intercultural Language Learning Visible and Assessable." CERCLL Proceedings of Intercultural Competence Conference, August 2010, CERCLL 1: 281-303, Tucson: Arizona.

Paunović, Tatjana. 2013. The Tangled Web: Intercultural Communicative Competence in EFL. Niš: Faculty of Philosophy.

Petrović, Dina. 2018. "Development of Intercultural Communicative Competence in an Electronic Environment." FACTA UNIVERSITATIS, Series: Linguistics and Literature Vol. 16, No 2: 121-132. https://doi.org/10.22190/FULL1802121P.

Radić-Bojanić, Biljana, and Nadežda Silaški. 2013. "Ethnocentrism and Intercultural Competence in Serbian Higher Education.” In M. Živković (Ed.), Multiculturalism and Contemporary Society, 273-282, Novi Sad: Fakultet za pravne i poslovne akademske studije "Dr Lazar Vrkatić".

Radić-Bojanić, Biljana. 2019. Interkulturalnost i kulturni identitet nastavnika engleskog jezika. Novi Sad: Filozofski fakultet.

Ruiz-Bernardo, Paola, Reina Ferrández-Berrueco, and María-Auxiliadora Sales-Ciges. 2012. "Application of the Cipp Model in the Study of Factors that Promote Intercultural Sensitivity." Revista Electrónica De Investigación Y Evaluación Educativa, 18 (2): 1-14.

Samovar, Larry, Richard Porter, Edwin McDaniel, and Carolyn Sexton Roy. 2013. Intercultural Communication. A Reader. Boston: Cengage Learning.

Scarino, A .2010. "Assessing Intercultural Capability in Learning Languages: A Renewed Understanding of Language, Culture, Learning, and the Nature of Assessment." The Modern Language Journal, 94 (2): 324-329.

Sercu, Lies. 2004. "Assessing Intercultural Competence: A Framework for Systematic Test Development in Foreign Language Education and Beyond.” Intercultural Education, Vol. 15, No. 1: 73-89.

Scollon, Ron, Suzanne Wong Scollon and Rodney H. Jones. 2012. Intercultural Communication: A Discourse Approach. Malden and Oxford: John Wiley \& Sons.

Sinicrope, Castle, John Norris, and Yukiko Watanabe, 2007. "Understanding and Assessing Intercultural Competence: A Summary of Theory, Research, and Practice." Second Language Studies, 26 (1): 1-58.

Spencer-Oatey, Helen. 2013. Critical Incidents. A Compilation of Quotations for the Intercultural Field. University of Warwick: GlobalIPAD Core Concepts.

Spencer-Oatey, Helen, and Peter Franklin. 2009. Intercultural Interaction. A Multidisciplinary Approach to Intercultural Communication. New York: Palgrave Macmillan. 
Spencer-Oatey, Helen, and Claudia Harsch. 2013. "The Critical Incident Technique.” In Z. Hua (Ed.), Research Methods in Intercultural Communication: A Practical Guide, 223-238. Chichester: John Wiley and Sons, Inc.

Storti, Craig. 1999. Figuring Foreigners Out: A Practical Guide. Yarmouth, MA: Intercultural Press.

Triandis, Harry. 1975. "Culture Training, Cognitive Complexity, and Interpersonal Attitudes." In R. W. Brislin, S. Bochner, and W. Lonner (Eds.), Cross-Cultural Perspectives on Learning, 39-77, Beverly Hills, CA: Sage Publications.

Triandis, Harry. 1995. “Culture-Specific Assimilators.” In S. M. Fowler, M. G. Mumford, (Eds.), Intercultural Sourcebook: Cross-Cultural Training Methods, Vol. 1, 179-186, Yarmouth, ME: Intercultural Press.

Webster, Leonard, and Patricie Mertova. 2007. Using Narrative Inquiry as a Research Method. An Introduction to Using Critical Event Narrative Analysis in Research on Learning and Teaching. London: Routledge.

Wight, Albert. 1995. "The critical incident as a training tool." In S. M. Fowler and M. G. Mumford (Eds.), Intercultural Sourcebook: Cross-Cultural Training Methods, Vol. 1, 127-40. Yarmouth, ME: Intercultural Press.

Woods, Peter. 2012. Critical Events in Teaching and Learning. London, Washington D.C.: The Falmer Press.

\section{KRITIČNE SITUACIJE KAO SREDSTVO RAZVIJANJA I PROCENE INTERKULTURNE OSETLJIVOSTI I KOMPETENCIJE STUDENATA ANGLISTIKE}

Poznavanje i razumevanje kulturnih vrednosti izvorne $i$ ciljnih kultura omogućava uspostavljanje $i$ održavanje uspešne interkulturne komunikacije. Cilj ovog rada jeste da istraži mišljenja i stavove studenata anglistike prema potencijalno konfliktnim interkulturnim situacijama. Za potrebe rada korišćena je kvalitativna tehnika analize kritičnih događaja kako bi se ustanovilo da li (i u kojoj meri) budući nastavnici engleskog kao stranog jezika poseduju interkulturnu osetljivost $i$ kompetenciju da reše konfliktne situacije predstavljene kroz tzv. kritične događaje. Istraživanje je sprovedeno među studentima treće $i$ četvrte godine anglistike na Filozofskom fakultetu Univerziteta u Novom Sadu. Rezultati istraživanja pokazuju da ispitanici imaju interkulturnu perspektivu $i$ visok nivo interkulturne osetljivosti $i$ kompetencije. Empirijski nalazi potvrđuju upotrebu kritičnih događaja kao jedne od mnogih korisnih pedagoških tehnika za razvijanje i procenu interkulturne osetljivosti $i$ kompetencije učenika/studenata stranog jezika. Pedagoške implikacije sprovedenog istraživanja ukazuju na neophodnost uvođenja interkulturnih elemenata ne samo u nastavu stranih jezika, već i u opšte obrazovanje.

Ključne reči: studenti anglistike, interkulturna osetljivost, interkulturna kompetencija, kritične situacije, interkulturna komunikacija. 